\title{
Persistence of sodium monofluoroacetate (1080) in fox baits and implications for fox management in south-eastern Australia
}

\author{
M. N. Gentle A,B,C,D , G. R. Saunders $^{\mathrm{A}}$ and C. R. Dickman ${ }^{\mathrm{B}}$

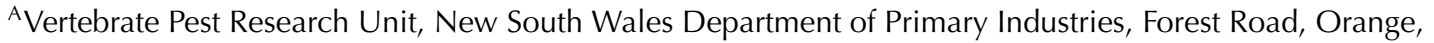 \\ NSW 2800, Australia. \\ ${ }^{B}$ Institute of Wildlife Research, School of Biological Sciences, University of Sydney, NSW 2006, Australia. \\ CPresent address: Robert Wicks Pest Animal Research Centre, Biosecurity Queensland, Department of Primary \\ Industries and Fisheries, 203 Tor Street, Toowoomba, Qld 4350, Australia. \\ DCorresponding author. Email: matthew.gentle@dpi.qld.gov.au
}

\begin{abstract}
The persistence of 1080 in two commonly used fox baits, Foxoff ${ }^{\circledR}$ and chicken wingettes, was assessed under different climatic and rainfall conditions in central-western New South Wales. The rate of 1080 degradation did not change significantly between the Central Tablelands and the relatively hotter and drier environment of the Western Slopes. Loss of 1080 from wingettes was independent of the rainfall and climate conditions, with wingettes remaining lethal to foxes for, on average, 0.9 weeks. Foxoff ${ }^{\circledR}$ baits remained lethal for longer than wingettes under all tested conditions, although their rate of degradation increased generally with increasing rainfall. As a result, areas baited with Foxoff ${ }^{\circledR}$ will require longer withholding periods for working dogs than those baited with wingettes, especially during dry periods. Wingettes may have advantages for use in sensitive areas where long-term hazards from toxic baits are undesirable. We found significant variations in 1080 concentration in freshly prepared baits that may result in efficacy, non-target and regulatory concerns for baiting campaigns. As a result, the superior quality control and shelf-stability of manufactured Foxoff ${ }^{\circledR}$ may be important criteria for favouring its use over freshly prepared bait types. However, use strategies for any bait type must ensure that foxes consume lethal doses of 1080 to avoid potential problems such as the development of learned aversion to baits or pesticide resistance.
\end{abstract}

\section{Introduction}

The European red fox (Vulpes vulpes) has become recognised as one of Australia's most significant vertebrate pests (McLeod 2004). Foxes are efficient predators of many wildlife species, contributing to numerous extinctions of native fauna (Dickman 1996; Kinnear et al. 2002). Foxes are also significant agricultural pests, especially as predators of newborn lambs and goat kids (Saunders et al. 1995). Many techniques are utilised on both agricultural and conservation lands for fox control but, despite research efforts directed towards development of new lethal and non-lethal control measures, we are still critically reliant upon the use of bait impregnated with sodium monofluoroacetate (1080) (Saunders and McLeod, in press).

Bait must retain its lethal dose of 1080 for a sufficient period to allow the target animal to find and consume the bait (McIlroy et al. 1986). The bait should also degrade so that non-target hazards from the 1080 are reduced and long-term environmental persistence is avoided (Calver and King 1986). Considerable effort has often been invested in improving the attractiveness and palatability of bait without regard to the persistence and longevity of 1080. Bait with long-lasting toxicity will almost certainly provide a potential hazard to farm dogs and other non-target species (Twigg et al. 2000). Additionally, public concern about the use of 1080 for vertebrate pest control in
Australia and New Zealand (King et al. 1994; Williams 1994; Oogjes 1996; Weaver 2003) supports the need to investigate, among other things, bait longevity and the environmental persistence of this toxin.

The longevity of 1080 baits prepared for various species is much reduced by rainfall (Griffiths 1959; Wheeler and Oliver 1978). In eastern Australia, Foxoff ${ }^{\circledR}$ loses $78 \%$ of the initial 3-mg dose after 2.4 weeks in moist soil conditions but may remain at lethal levels for more than 11 weeks when not exposed to rain (Saunders et al. 2000). Unburied fresh meat bait for wild dogs (6.1 mg nominal dose) may be viable for 6-12 months in the drier conditions of central Australia (Twigg et al. 2000) compared with $<2$ months in more temperate areas (McIlroy and Gifford 1988; Fleming and Parker 1991). Egg baits injected with $4.5 \mathrm{mg}$ of 1080 remain lethal to foxes for at least 6 weeks, even after considerable $(>80 \mathrm{~mm})$ rainfall (Twigg et al. 2001). Kirkpatrick (1999) found that buried dried meat baits remain lethal to foxes for 7 weeks if exposed to little rainfall, but last only a week if rainfall is moderate. These studies all indicate that rainfall and climate are important determinants of bait longevity, and should be included as factors in investigations of any bait intended for widespread use in fox control programs.

Chicken wingettes have been used as 1080 fox baits in New South Wales since they were approved in 1998. Preliminary 
trials have shown that chicken wingettes injected with 1080 have reduced leakage of 1080 compared with red meat (T. Abblett, Wentworth Rural Lands Protection Board, pers. comm. 2001), suggesting greater retention of poison and consistency of lethal dose. Microbes found in bait materials are capable of defluorinating 1080 (Wong et al. 1991). Primary processing for poultry differs from red meat in ways that increase microbiological contamination and spoilage rates, suggesting that wingettes may have reduced longevity compared with other bait types (Frazier and Westhoff 1978; Adams and Moss 1995). No studies have yet assessed 1080 longevity in chicken wingettes or any other chicken substrate. Given that their use is becoming increasingly popular (West and Saunders 2003), their rate of degradation requires assessment to determine appropriate use strategies.

In this paper, the rate of 1080 degradation in chicken wingettes (hereafter called wingettes) is investigated under two climatic and three rainfall regimes to assess their potential longevity and effectiveness for fox-control programs in eastern Australia. The degradation of wingettes relative to Foxoff ${ }^{\circledR}$, a commonly used, commercially manufactured bait type, is compared for the Central Tablelands and Western Slopes of New South Wales, from original and published data (Saunders et al. 2000). Decay models are constructed to examine the relationship between 1080 loss and rainfall, and to provide a predictive model for bait longevity for each bait type under average climatic conditions. Finally, we discuss the likely determinants of 1080 loss from bait and the implications of these findings for baiting programs.

\section{Methods}

The study was undertaken at Trangie Research Station $\left(31^{\circ} 59^{\prime} \mathrm{S}, 147^{\circ} 57^{\prime} \mathrm{E}\right)$ and Orange Agricultural Institute $\left(33^{\circ} 18^{\prime} \mathrm{S}\right.$, $\left.149^{\circ} 05^{\prime} \mathrm{E}\right)$, New South Wales. Trangie Research Station (TRS) is situated $5 \mathrm{~km}$ west of Trangie on the central Western Slopes and plains and comprises native grassland for grazing and small areas of flood irrigation for cotton and lucerne pasture (Robards and Michalk 1975). The Orange Agricultural Institute (OAI) is situated on the southern outskirts of Orange on the Central Tablelands, and comprises mainly improved pastures for sheep and cattle grazing. Both sites are representative of lands in each region where fox baiting is likely to be undertaken by landholders.

Trials at both sites were undertaken between spring and summer 2001 to coincide with spring baiting campaigns typically undertaken by landholders. For each trial, baits were buried on Day 0 and removed at weekly intervals for a total of 10 weeks. Methods were consistent with those of Saunders et al. (2000) to allow for comparison of results.

At OAI, three treatments were undertaken, each consisting of wingettes exposed to a different rainfall regime. The treatments were: (1) mean weekly rainfall, (2) prevailing rainfall, and (3) no rainfall.

The amount of artificial rainfall applied to the treatment 'mean weekly rainfall' was calculated from the local longterm weekly rainfall averages for the trial period (OctoberDecember). At OAI, the treatment 'mean weekly rainfall' required applying a measured amount of water at weekly intervals. 'Prevailing rainfall' offered no protection to the bait.
'No rainfall' consisted of protecting the bait, so no natural or artificial rain was applied during the trial period. At TRS, two bait types were tested; Foxoff ${ }^{\circledR}$ and wingettes, with both bait types subjected only to the treatment 'prevailing rainfall'.

All baits were prepared and/or stored as per the standard for fox-control programs in New South Wales. Wingettes were injected with $0.1 \mathrm{~mL}$ of a nominal $30 \mathrm{mg} \mathrm{mL}^{-1} 1080$ stock solution (made from 90\% pure Rentokil Tenate brand 1080 powder) to give a nominal 3-mg dose. Graduated (1 mL) syringes were filled individually to $0.1 \mathrm{~mL}$ and injected into each wingette. Given the slight variation in the volume injected by syringes, and the concentration of the stock solution, the 3-mg dose was only nominal (see Results). A 5-g sample of the powder concentrate was stored at room temperature and a $10-\mathrm{mL}$ sample of each stock solution was frozen for later analyses. Foxoff ${ }^{\circledR}$ baits are commercially manufactured and do not require injection with 1080. All Foxoff ${ }^{\circledR}$ baits were from the same manufacturing batch and were shelf-stored until use. Baits were randomly allocated to treatments, and stored in plastic bags.

Level burial sites at TRS and OAI were selected to avoid run-off of water from surrounding areas and fenced to exclude stock. Baits were buried $5 \mathrm{~cm}$ below the surface to simulate the recommended bait-placement procedures for baiting operations on agricultural lands in New South Wales (Environment Protection Authority 2002; Saunders and McLeod, in press). A soil corer was used to ensure that all baits were buried at the same depth. Baits were buried in 300-mm lengths of 100-mmdiameter PVC stormwater pipe that had previously been buried to a depth of $200 \mathrm{~mm}$. The PVC pipe was aligned vertically to shelter the bait from runoff from surrounding soil but still allow normal microorganism activity (Saunders et al. 2000). All baits were positioned at least $50 \mathrm{~cm}$ apart. The open top of each PVC pipe for the treatments 'no rainfall' and 'mean weekly rainfall' was covered with a transparent square $(250 \mathrm{~mm} \times 250 \mathrm{~mm})$ of Laserlite $2000{ }^{\circledR}$ (Laserlite, Cheltenham, Victoria) held in place by a small weight. This sheeting allowed the soil on top of the bait access to light and air, but protected it from natural rainfall. All baits were covered with predator-proof mesh cages to prevent their disturbance or removal by mammals and birds. At weekly sampling periods, five baits from each treatment were removed and placed in individually numbered plastic bags. All retrieved baits remained frozen at $-18^{\circ} \mathrm{C}$ until analysed. A sample of soil $(80 \mathrm{~g})$ was removed from underneath each bait, placed in a foil tray, weighed, and oven-dried at $80^{\circ} \mathrm{C}$ for three days to calculate soil moisture levels.

Rainfall $\left(\mathrm{mm} \mathrm{day}^{-1}\right)$ and minimum and maximum ambient temperature $\left({ }^{\circ} \mathrm{C}\right)$ were recorded daily at each site. Soil temperature at $10 \mathrm{~cm}$ was recorded daily at OAI and on weekdays at TRS.

\section{0 content assays}

The 1080 content of bait was assayed using gas chromatography following Ozawa and Tsukioka (1989) and conducted by the Alan Fletcher Research Station, Queensland Natural Resources, Mines and Water, using their routine 1080 analysis procedures. The detection levels were $\geq 0.07 \mathrm{mg}$. The purity of the stock solution and concentrate powder were tested using the derivation from the high-performance liquid chromatography method (Kramer 1984). The determination level was $50 \mu \mathrm{g} \mathrm{mL}^{-1}$. 


\section{Statistical analyses}

Regression analysis using random regression models was used to model the changes in 1080 concentration over time, and to provide a predictive model of the decay rate (Twigg et al. 2000). Included in the model for a given site/year were fixed regression effects for bait type and treatment; this model was later extended for comparisons between sites. Differences in the mean regression parameter for the $\log (1080$ concentration) for bait types and treatments were examined using ANOVA. The model was fitted to data only up to the time that all subsequent baits had no detectable 1080. As results were recorded as zero, when 1080 was undetectable (i.e. $<0.07 \mathrm{mg}$ ), the data used in the model correspond to $\log (x+0.06)$ with $x$ the recorded 1080 concentration. Model parameters were estimated using residual maximum likelihood to reduce bias associated with estimation of the fixed parameters (Venables and Ripley 2002).

\section{Results}

\section{Weather data}

The rainfall patterns in each month of the trial periods and relationships relative to the long-term median rainfall for TRS (1922-2001) and OAI (1966-2001) are shown in Table 1.

The average daily maximum $\left(28.7^{\circ} \mathrm{C}\right)$ and minimum $\left(13.1^{\circ} \mathrm{C}\right)$ at TRS were consistently greater than at $\mathrm{OAI}\left(19.2^{\circ} \mathrm{C}\right.$ and $7.5^{\circ} \mathrm{C}$ respectively). Soil temperature at $10 \mathrm{~cm}$ was less variable than the ambient air temperature but still reflected the site differences (Fig. 1). The average for TRS $\left(21.2^{\circ} \mathrm{C}\right)$ was over $6^{\circ} \mathrm{C}$ warmer than that for OAI $\left(14.6^{\circ} \mathrm{C}\right)$.

\section{Injection calibration and stock solution}

The mean ( \pm s.d.) amount of stock solution injected for a single dose using the syringe technique was $0.095 \pm 0.003 \mathrm{~mL}$ (range $=0.089-0.102, n=30$ ). If the stock solution contained the nominal $30.00 \mathrm{mg} \mathrm{mL}^{-1} 1080$ concentration, the mean dose injected into each bait would have been $2.85 \pm 0.11 \mathrm{mg}$ (expected range $=2.66-3.05$ ). Later analyses revealed that a sample of the stock solution contained $36.04 \mathrm{mg} \mathrm{mL}^{-1}$ at the time of preparing the OAI baits, and $31.96 \mathrm{mg} \mathrm{mL}^{-1}$ when the TRS baits were prepared. As aqueous 1080 solution stored at room temperature remains stable for at least 12 months (R. Parker, Natural Resources and Water, pers. comm. 2005), the variation between the two samples is probably due to measurement error in the assay process. Therefore, using a mean of the two solution subsamples, the average dose per bait equates to $3.23 \pm 0.12 \mathrm{mg} 1080$ (range $=3.01-3.45)$.

Table 1. The amount of rainfall ( $\mathrm{mm})$ that fell in the month before and during the trial period at the two study sites in 2001

The amount of rainfall $(\mathrm{mm})$ that fell is shown relative to the long-term median; for example, +32 is $32 \mathrm{~mm}$ greater than the median

\begin{tabular}{lcccc}
\hline Month & $\begin{array}{c}\text { Orange Agricultural Institute } \\
\text { Rainfall }(\mathrm{mm})\end{array}$ & $\begin{array}{c}\text { Trangie Research Station } \\
\pm \text { Median }\end{array}$ & $\begin{array}{c}\text { Rainfall (mm) } \\
\pm \text { Median }\end{array}$ \\
\hline September & 85.0 & 0 & 26.0 & -2.3 \\
October & 94.0 & +12.2 & 48.9 & +14.1 \\
November & 44.0 & -22.0 & 19.6 & -16.8 \\
December & 26.9 & -36.1 & 13.6 & -18.7 \\
\hline
\end{tabular}

\section{0 content}

There was a large variation in the 1080 concentration of the wingette Day 0 baits. The mean ( \pm s.d.) in Day 0 wingettes at TRS was $3.84 \pm 0.85 \mathrm{mg}(n=8)$, and at OAI $3.16 \pm 1.53 \mathrm{mg}$ $(n=3)$. Both OAI and TRS samples contained baits that had doses greater than 1.5 times the nominal dose of $3 \mathrm{mg}$. The mean of the Day 0 Foxoff ${ }^{\circledR}$ baits was $2.97 \pm 1.08 \mathrm{mg}(n=4)$.

\section{0 degradation}

Statistical tests were performed only using data up to the time when all subsequent baits had no detectable 1080. At OAI this included data up to and including Week 3; at TRS, up to and including Week 5.

A separate ANOVA was undertaken for each site to examine within-site differences. Additionally, a StudentNeuman-Keuls (SNK) multiple-range test (Snedecor and Cochran 1989) was undertaken to examine the relationship between each factor (Bait type, Site, Treatment) for each week of the trial.

Comparisons of 1080 concentrations of wingettes at OAI revealed significant differences in the factor Time $\left(F_{3,22}=140.47, P<0.001\right)$, but not Treatment $\left(F_{2,22}=0.28\right.$, $P=0.758)$. There was also no interaction between Treatment and Time $\left(F_{6,22}=0.01, P=0.991\right)$, indicating no difference in the decay rate of 1080 between treatments during the course of the experiment. Treatments were therefore combined.

There was no significant difference in the rate of 1080 decay in wingettes at OAI and TRS for the treatment 'mean weekly rainfall' $\left(F_{1,23}=2.51, P=0.127\right)$, despite a significant rate of 1080 decay over time $\left(F_{3,23}=67.99, P<0.001\right)$. Moreover, the interaction of Site and Time was not significant $\left(F_{3,23}=0.72, P=0.405\right)$. Nevertheless, a separate predictive model of the 1080 degradation of wingettes is presented for both TRS and OAI.

Comparison of the 1080 concentrations in wingettes and Foxoff $^{\circledR}$ at TRS showed a significant difference in the Type of bait $\left(F_{1,23}=10.48, P<0.001\right)$ and Time $\left(F_{4,23}=98.31\right.$,

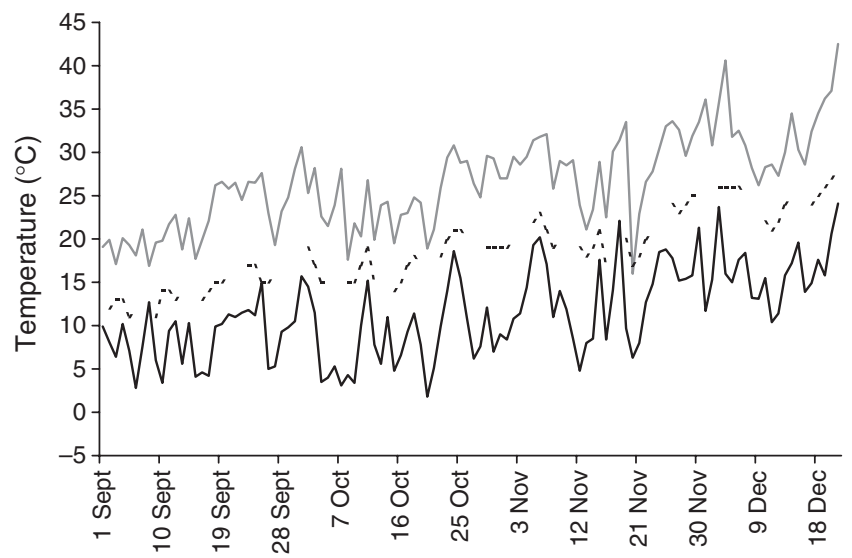

Fig. 1. Daily ambient and soil temperature at TRS for the period immediately before and during the study period, specifically 10 October to 21 December 2001. Minimum temperature, solid black line; maximum temperature, solid grey line; and soil temperature, dashed line. Note: soil temperature was measured only during weekdays. 
$P<0.001)$, but no interaction between the Type of bait and Time $\left(F_{4,23}=1.84, P=0.189\right)$.

Data from a previous study that measured the 1080 degradation rate of buried Foxoff ${ }^{\circledR}$ at OAI (Saunders et al. 2000) were compared with the rate of decay in wingettes collected at the same site in this study. An ANOVA was used to compare the rate of 1080 decay in Foxoff ${ }^{\circledR}$ and wingettes for the wet treatments common to both studies, 'mean weekly rainfall' and 'prevailing rainfall'. A separate ANOVA was used to compare the dry treatments, 'no rain'. There was a difference between the wet treatments for Foxoff ${ }^{\circledR}$ and wingettes in the interaction between Type of bait and Time $\left(F_{5,111}=11.83, P<0.001\right)$, indicating a difference in degradation rates. The lack of significance in the Type of bait $\left(F_{1,111}=0.31, P=0.580\right)$ indicates that there was no difference in the amount of 1080 at the start of the experiment (Day 0). For the treatment 'no rain', there was a difference in the rate of decay for wingettes and Foxoff ${ }^{\circledR}$, indicated by a significant Type of bait and Time interaction $\left(F_{4,65}=41.51, P<0.001\right)$. However, there was a significant difference in the rate of decay of the treatment 'mean weekly rainfall' for Foxoff ${ }^{\circledR}$ at TRS and OAI $\left(F_{1,61}=23.72, P<0.001\right)$.

SNK tests revealed no significant difference in the amount of 1080 among treatments at Week $0(P>0.05)$, but at Week 1 and Week 3, two separate groups were apparent: Foxoff ${ }^{\circledR}$ at TRS and the wingette treatments on both sites. At all other times there were no significant differences between the treatments $(P>0.05)$. A second multiple-range test compared the weekly mean 1080 content in Foxoff $^{\circledR}$ at OAI from an earlier trial (Saunders et al. 2000) with Foxoff ${ }^{\circledR}$ and wingettes in this trial for the first five weeks. After Week 1, all Foxoff ${ }^{\circledR}$ treatments were significantly different $(P<0.05)$ from all wingette treatments, both at OAI and TRS. During Weeks 2 and 3 there were no significant differences $(P>0.05)$ between any treatments. At Week 4, three distinct groups were present: (1) the Foxoff ${ }^{\circledR}$ treatment 'no rain' at OAI; (2) Foxoff ${ }^{\circledR}$ treatments 'mean weekly rainfall' and 'prevailing rainfall' at OAI; and (3) all wingette treatments from OAI and wingettes and Foxoff ${ }^{\circledR}$ at TRS. At Week 5, only the Foxoff ${ }^{\circledR}$ treatment 'no rain' was significantly different $(P<0.05)$ from any other treatment.

A two-way fixed-factor ANOVA of soil moisture content for all treatments at OAI revealed no significant difference in the amount of moisture in each treatment $\left(F_{2,44}=1.54, P>0.05\right)$ during any week $\left(F_{2,44}=1.75, P>0.05\right)$ or any interaction between week and treatment $\left(F_{4,44}=0.65, P>0.05\right)$. Similarly, there was no difference between the OAI and TRS wingettes treatment 'mean weekly rainfall' for site $\left(F_{1,23}=0.11, P>0.05\right)$ or time $\left(F_{3,23}=0.82, P>0.05\right)$ or interaction between the two $\left(F_{3,23}=0.56, P>0.05\right)$.

\section{Discussion}

The amount of 1080 in the stock solution used at both TRS (31.96 $\left.\mathrm{mg} \mathrm{mL}^{-1}\right)$ and OAI $\left(36.04 \mathrm{mg} \mathrm{mL}^{-1}\right)$ was greater than the nominal $30.00 \mathrm{mg} \mathrm{mL}^{-1}$. This greater than expected concentration of the stock solution is most likely due to the high purity of the 1080 powder (assayed at $1139 \pm 131 \mathrm{~g} \mathrm{~kg}^{-1}$, essentially $100 \%$ pure) used to make the solution. The variation between the two stock solution samples is at first worrying; the identical stock solution was used to inject both OAI and TRS baits, but the TRS baits were injected five days later. The difference in 1080 concentration was probably not caused by degradation of the solution. Two sources of error are possible; the solution may not have been uniformly mixed, resulting in some precipitation in the solution between injection periods, or there was error associated with the assay process. The latter explanation is more likely; the overall percentage recovery of 1080 from control solutions was $106 \%$ (s.d. $=9.8 \%, n=6$ ) (Hannan-Jones 2002). The variation between stock solution samples is within the control sample standard deviation $(9.8 \%)$ of the mean of the two solutions $\left(34.00 \mathrm{mg} \mathrm{mL}^{-1}\right)$. Given the variation in the measured concentration of 1080 solutions, it is probably safe to assume that the mean was $\sim 34.00 \mathrm{mg} \mathrm{mL}^{-1}$, which is some $13 \%$ greater than the nominal concentration $\left(30.00 \mathrm{mg} \mathrm{mL}^{-1}\right)$. This indicates that the mixing of the stock solution, originally calculated for a powder purity level of $90 \%$, was reasonably accurate.

The 1080 content of freshly prepared bait appears to be highly variable. With some baits measured at almost twice the nominal concentration, it is almost inconceivable that all of this variation is due to injection error, given the accuracy of the injected dose and the concentration of the stock solution. Other studies have also reported, or presented, data showing high variability in 1080 concentration in fresh meat bait (e.g. Korn and Livanos 1986; McIlroy et al. 1986; Kramer and Merrell 1987; McIlroy and Gifford 1988; Fleming and Parker 1991; Twigg et al. 2000), despite using a variety of bait substrates, solution concentrations and volumes, and application techniques. A recent study (A. Claridge, Department of Environment and Conservation, unpub. data) further illustrates this variation: fresh meat baits injected using syringes for a 6.0-mg nominal dose averaged $5.97 \pm 1.49 \mathrm{mg}$ (range $=4.23-8.60$ ). The ability of 1080 to bind to meat, amplified by the time lag between injection and analysis, means that the percentage recovery of 1080 (relative to the injected dose) is low (Frost et al. 1989; Fleming and Parker 1991). Given that 1080 recovery within substrates varies according to the substrate type (Frost et al. 1989) and composition (R. Parker, Department of Primary Industries and Fisheries, pers. comm. 2003), it appears that variation in tissue composition between individual baits may result in variations in the measured concentration. The calculated variation may then be compounded by correcting the (low) measured recovery rate. Conflicting recoveries within samples would cause error in the corrected estimates of 1080 concentration.

Variable recovery is less problematic after physical degradation, allowing for more consistent recovery from the bait substrate. As meat physically degrades, the ability of 1080 to bind decreases (Kramer and Merrell 1987) and the potential for leaching increases (e.g. McIlroy and Gifford 1988); this suggests more efficient water extraction, in turn reducing variable recovery. Even though Week 0 baits showed large variation in recoverable 1080, the results from Week 1 onwards, when all baits showed signs of physical deterioration, were less affected by variable recovery and thus better reflect the true 1080 concentrations and losses from degradation processes.

Leakage or seepage of the stock solution from baits after injection is probably not responsible for the lower 1080 content of wingettes. Leakage does not affect the recovery of 1080 from meat baits unless a sufficiently large volume is injected to cause the solution to leak out. Only occasional leakage was reported by 
Kramer and Merrell (1987) during injections of a large amount of stock solution $(1 \mathrm{~mL})$ into thinly sliced fresh meat baits; no leakage was observed when the injected dose was halved to $0.5 \mathrm{~mL}$. The small injection volume used in this study $(0.1 \mathrm{~mL})$ would mean that leakage would be even less likely. Seepage may be adsorbed to the surface of the baits (Korn and Livanos 1986), adding a multiplicable source of variation in 1080 content when many baits are transported within the same container, as seepage from one bait may adhere to the surface of another (Fleming and Parker 1991). In this study, each bait was bagged individually; if seepage did occur, it would account for loss of 1080 only within baits and not contamination of 1080 from one bait to another.

Historically, tested batches of Foxoff ${ }^{\circledR}$ baits have shown little variation in 1080 concentration $(2.74 \pm 0.42 \mathrm{mg})$ (R. Parker, Department of Primary Industries and Fisheries, pers. comm. 2002). Although it is impossible to confirm, the relative accuracy of the injection technique compared with the assay results suggests that the variation in 1080 content in wingettes is a consequence of binding differences in the bait substrates. The Foxoff ${ }^{\circledR}$ bait matrix may be more uniform due to the manufacturing process, resulting in greater consistency in 1080 recovery. Regardless, the high variability of 1080 in freshly prepared bait, especially fresh meat, should be further investigated to ensure that consistent doses are presented in baits prepared for use in the field. This is extremely important in terms of efficacy (reduced nominal dose) and non-target safety (increased nominal dose).

The results indicate no difference in the rate of 1080 loss from wingettes in the rainfall treatments 'mean weekly rainfall', 'prevailing rainfall' and 'no rainfall' at OAI. Up to Week 3, considerably more rain $(79.6 \mathrm{~mm})$ fell on the baits in the 'prevailing rainfall' treatment, than was added to the 'mean weekly rainfall' treatment $(45 \mathrm{~mm})$. Surface-laid fresh meat baits lose more 1080 from leaching if subjected to rain on the first day (McIlroy et al. 1986) before the surface dries to form a crust. The crust then offers some protection against leaching until baits begin to physically degrade (Fleming and Parker 1991). The similarities between decay rates in all three treatments despite differences in the amount and pattern of rainfall suggest that leaching of 1080 was not an important mechanism for the degradation of wingettes. This is further supported by the insignificant difference between 1080 loss from wingettes at TRS and OAI, despite $13 \mathrm{~mm}$ of rain falling on the baits (on Day 0) at TRS. It is likely that a threshold level of soil moisture is required to initiate the degradation process (e.g. Saunders et al. 2000; Twigg et al. 2000), a level reached in all treatments in this study $(>15 \%)$.

Comparisons between wingettes and Foxoff ${ }^{\circledR}$ at TRS and OAI suggest little difference in bait degradation rates at the two study sites. The mean soil temperature at $\operatorname{TRS}\left(21^{\circ} \mathrm{C}\right)$ was higher during the trial period than that at OAI $\left(14.6^{\circ} \mathrm{C}\right)$, but the amount of artificial rain added each week was less $(11 \mathrm{~mm}$ versus $19.5 \mathrm{~mm})$. Evaporation at TRS $(258 \mathrm{~mm})$ was also greater than at OAI $(165 \mathrm{~mm})$ during the trial period. Warmer conditions favour heightened bacterial and fungal growth, leading to faster defluorination. Defluorination at $20^{\circ} \mathrm{C}$ is three times faster than at $10^{\circ} \mathrm{C}$ (Parfitt et al. 1994), suggesting that if other factors were the same, baits at TRS would be shorter lived. However, the additional rainfall at OAI may have assisted the leaching of 1080 from the bait following physical degradation. Also, the rain $(13 \mathrm{~mm})$ that all baits received at TRS on Day 1 may have helped to initiate the degradation process, which appeared uninfluenced by the greater evaporative loss during the trial period. Either way, both sites showed remarkably similar degradation rates for both wingettes and Foxoff ${ }^{\circledR}$.

Saunders et al. (2000) found that Foxoff ${ }^{\circledR}$ exposed to no rain generally remained toxic for longer than when exposed to any amount of rain, despite the lack of a statistically significant difference in soil moisture between the treatments. The loss of 1080 from wingettes was independent of rainfall, suggesting that the 'washing through' effect of rainfall (leaching) has more influence on 1080 loss from Foxoff ${ }^{\circledR}$ than from wingettes. 1080 loss from wingettes is most likely caused by biological rather than meteorological factors.

One possible factor affecting the leaching of 1080 from bait was the application of the artificial 'mean weekly rainfall' treatment. In this treatment, the total volume of the average weekly rainfall was applied once a week. Obviously, application of artificial rainfall in this manner may vary from the natural pattern in which rain may fall on several occasions and at different intensities throughout the week. Our protocol may have increased the 'washing though' effect of the rain, increasing the leaching of 1080 from the bait. However, the results indicate that it did not influence the rate of wingette degradation compared with natural rainfall conditions given the lack of any leaching effect, and the insignificant differences between the 'mean weekly rainfall' and the 'prevailing rainfall' treatments at OAI. Similarly, it is unlikely to have exaggerated the leaching effect on Foxoff ${ }^{\circledR}$ given the lack of difference between artificial and natural rainfall treatments reported by Saunders et al. (2000). Nevertheless, the pattern of rainfall should be considered when assessing rates of 1080 bait degradation.

The presence and defluorinating ability of microorganisms varies widely with different bait materials (Wong et al. 1991). Microbial contamination can occur during handling, preparation and storage of bait. Defluorination rates are generally high in fresh meat baits due to the organic, carbon-rich environment that supports microorganisms (Wong et al. 1991). Biochemical, enzymic reactions also physically degrade meat (Adams and Moss 1995). As a result, the 1080 concentration in fresh meat baits will decline under moisture and temperature conditions favourable to microorganisms and enzymic reactions. However, when stored in similar conditions the Foxoff ${ }^{\circledR}$ bait matrix appears to be a poor environment for defluorinating microorganisms. This is probably due to the combination of low initial abundance of 1080-detoxifying organisms in the bait and deficient environmental conditions for their growth. The low moisture content of Foxoff ${ }^{\circledR}(5.3 \pm 1.4 \%)$ relative to wingettes $(54.4 \pm 1.4 \%)$ may be responsible, as microorganisms will metabolise substrates only when sufficient water is available (Parfitt et al. 1994). In terms of 1080 content, Foxoff ${ }^{\circledR}$ is highly shelf-stable; in temperature and humidity conditions conducive to biological degradation, Foxoff ${ }^{\circledR}$ retains $97 \%$ of its initial 1080 for more than six months (Staples et al. 1995). Independent of other factors, the above results suggest that 1080 in wingettes degrades at a faster rate than in Foxoff ${ }^{\circledR}$ due solely to biochemical and microbial activity. 
Insects are also known to contribute to bait decay (Eastman and Calver 1988; McIlroy and Gifford 1988; Fleming and Parker 1991). In this study, the degradation of wingettes was probably assisted by insect consumption, especially from blowfly maggots (calliphorid larvae). These consume bait material with 1080 (McIlroy and Gifford 1988), resulting in significant losses. Maggots were observed on wingettes as early as Week 1 but were more common during Weeks 2 and 3. No maggots were observed on Foxoff ${ }^{\circledR}$ baits at any time.

\section{Management implications}

Data from this study can be used to estimate the time that bait will present a lethal dose for foxes (see Table 2). These estimates are not universal, but are representative of the situations likely to be encountered in eastern and mid-western New South Wales. The average bodyweight of an adult fox on the central tablelands is $5 \mathrm{~kg}$ (Winstanley et al. 1999); foxes in the drier, less productive Western Slopes region may average slightly less. The lethal dose for foxes is $0.15 \mathrm{mg} \mathrm{kg}^{-1}$ (McIlroy and King 1990), which equates to a lethal dose of $0.75 \mathrm{mg}$ for an adult. Given that baiting campaigns aim to present lethal baits to foxes, the lethal dose required to kill most foxes (rather than only $50 \%$, as based on a $\mathrm{LD}_{50}$ ) was used to estimate the longevity of bait types. Applying this to the fitted decay curve for wingettes buried and exposed to various rainfall regimes on the central tablelands (Fig. 2), wingettes should remain lethal to foxes for a mean of 0.9 weeks (Table 2). The 0.05 and 0.95 quartile confidence limits fitted to the model estimate that $95 \%$ of baits will remain lethal for up to 0.4 weeks, decreasing rapidly to leave only $5 \%$ lethal at 1.7 weeks. Similarly, wingettes on the Western Slopes should reach $0.75 \mathrm{mg}$ of 1080 at 0.9 weeks; $95 \%$ are lethal at 0.6 weeks but $95 \%$ fall below a lethal dose 1.4 weeks after burial (Fig. 3).

Foxoff ${ }^{\circledR}$ baits degrade at a slower rate than wingettes and therefore remain lethal to foxes for longer. Under average rainfall conditions on the western slopes of New South Wales, Foxoff ${ }^{\circledR}$ retains $0.75 \mathrm{mg}$ of 1080 for an average of 2.0 weeks after burial, with $95 \%$ remaining lethal for at least 0.9 weeks and $95 \%$

Table 2. The amount of $\mathbf{1 0 8 0}$ required for a lethal dose and mean time (in weeks) that wingettes and Foxoff ${ }^{\circledR}$ remain lethal to foxes, sheep dogs and cattle dogs after bait is laid

Figures in parentheses are the estimated $5 \%$ and $95 \%$ population levels that represent lethal doses for foxes $\left(\sim \mathrm{LD}_{100}\right)$, and domestic dogs $\left(\sim \mathrm{LD}_{17}\right)$. Based on Fleming and Parker (1991)

\begin{tabular}{|c|c|c|c|}
\hline & \multicolumn{3}{|c|}{ Species } \\
\hline & Fox & Sheep dog & Cattle dog \\
\hline $\begin{array}{l}\text { Approximate amount } \\
1080(\mathrm{mg}) \text { required } \\
\text { for lethal dose }\end{array}$ & 0.75 & 0.75 & 1.00 \\
\hline $\begin{array}{l}\text { Wingette (Central } \\
\text { Tablelands) - mean time } \\
\text { (weeks) } \geq \text { lethal dose }\end{array}$ & $0.9(0.4-1.7)$ & $0.9(0.4-1.7)$ & $0.7(0.3-1.5)$ \\
\hline $\begin{array}{l}\text { Wingette (Western Slopes) } \\
- \text { mean time (weeks) } \\
\geq \text { lethal dose }\end{array}$ & $0.9(0.6-1.4)$ & $0.9(0.6-1.4)$ & $0.7(0.5-1.2)$ \\
\hline $\begin{array}{l}\text { Foxoff }^{\circledR} \text { (Western Slopes) } \\
\quad-\text { mean time (weeks) } \\
\geq \text { lethal dose }\end{array}$ & $2.0(0.9-4.7)$ & $2.0(0.9-4.7)$ & $1.6(0.6-4.0)$ \\
\hline
\end{tabular}

degrading to below lethal levels by 4.7 weeks (Fig. 4). These results confirm previous studies. Saunders et al. (2000) found that Foxoff ${ }^{\circledR}$ exposed to various amounts of artificial rainfall on the Central Tablelands reached $\mathrm{LD}_{50}$ levels $(0.65 \mathrm{mg})$ after 2.4 weeks (compared with 2.1 weeks in the current study). The difference between these two results is insignificant (as tested

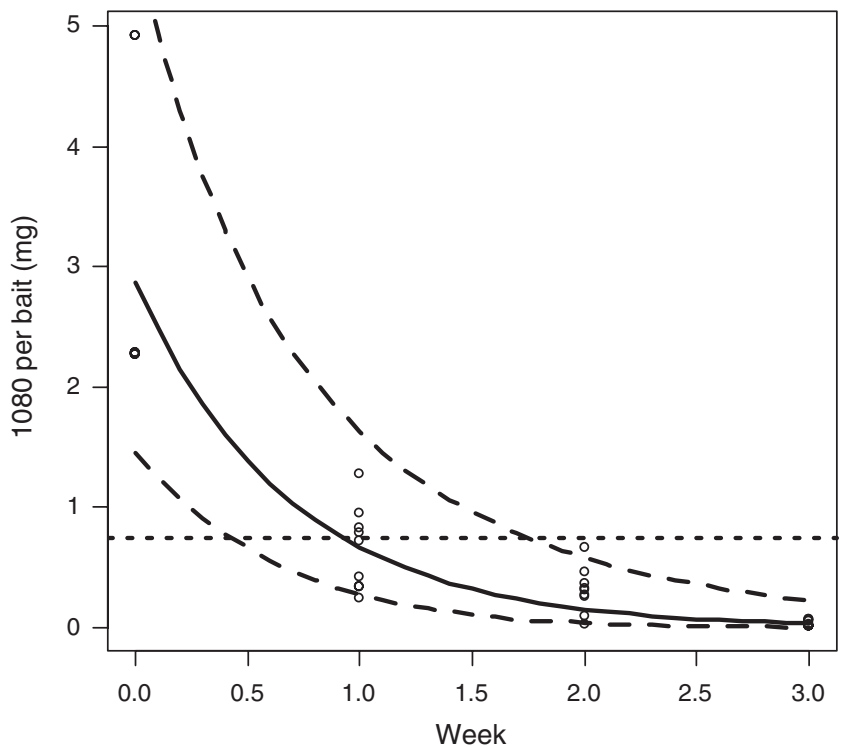

Fig. 2. Fitted curves for the mean loss of 1080 (solid line) and 0.05 and 0.95 quantiles for wingettes at OAI exposed to 'mean weekly rainfall', 'prevailing rainfall' and 'no rain' up to and including three weeks after initial burial. Dotted line indicates a lethal dose $(0.75 \mathrm{mg})$ for a $5-\mathrm{kg}$ fox.

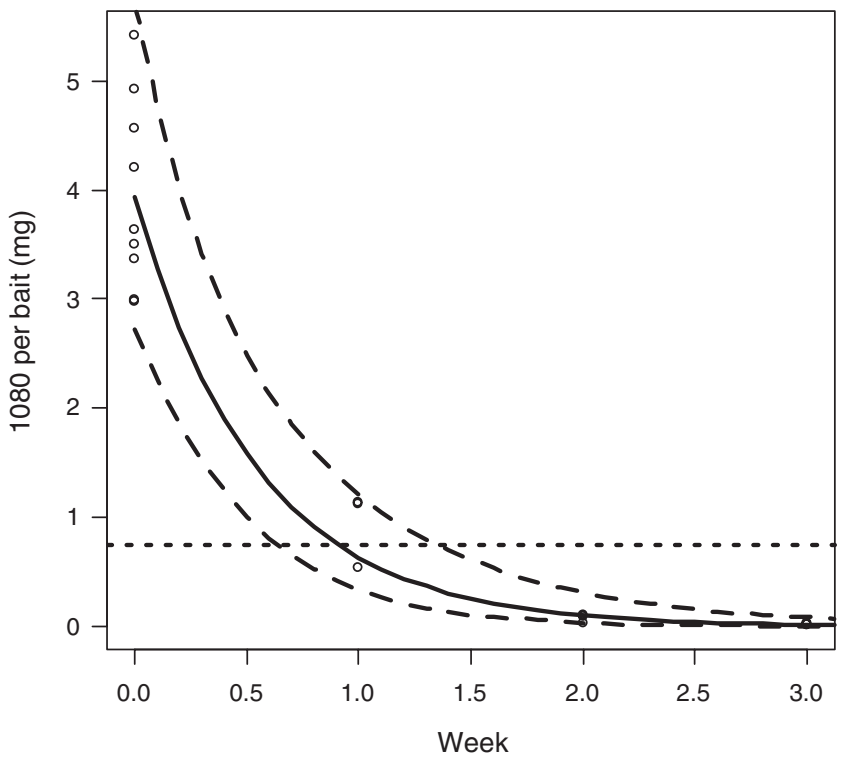

Fig. 3. Fitted curves for the mean loss of 1080 (solid line) and 0.05 and 0.95 quantiles for wingettes at TRS exposed to 'mean weekly rainfall' up to and including three weeks after initial burial. Dotted line indicates a lethal dose $(0.75 \mathrm{mg})$ for a $5-\mathrm{kg}$ fox. 


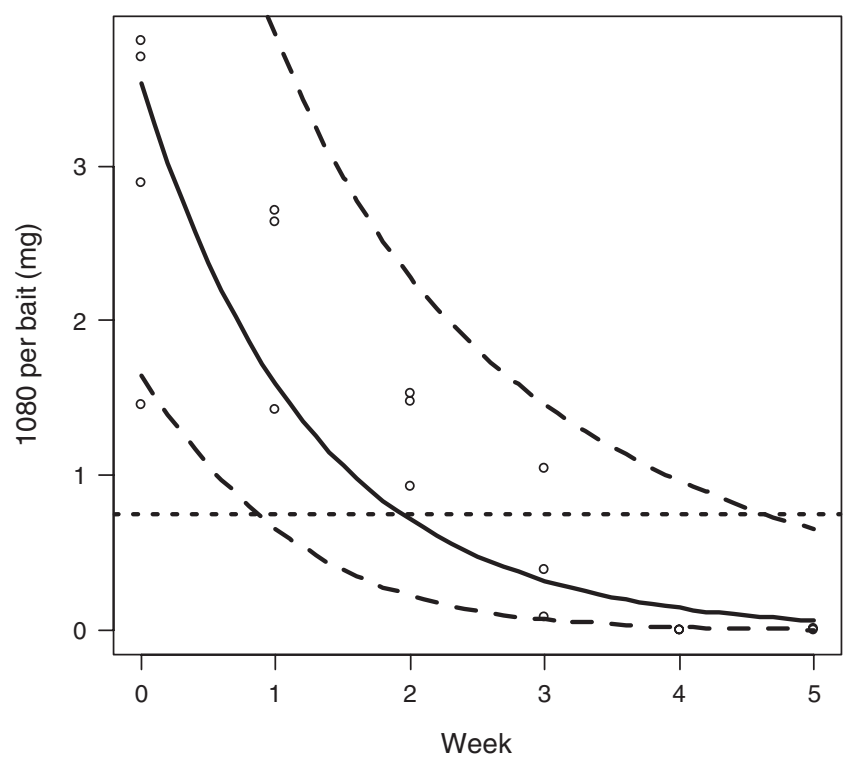

Fig. 4. Fitted curves for the mean loss of 1080 (solid line) and 0.05 and 0.95 quantiles for Foxoff ${ }^{\circledR}$ at TRS exposed to 'mean weekly rainfall' up to and including five weeks after initial burial. Dotted line indicates a lethal dose $(0.75 \mathrm{mg})$ for a $5-\mathrm{kg}$ fox.

earlier) and probably due to the differences in the fitted models. Staples et al. (1995) tested the longevity of 60-g Foxoff ${ }^{\circledR}$ baits containing $3.3 \mathrm{mg}$ of 1080 in both wet and dry soil conditions. Despite the larger bait matrix (60 g versus $30 \mathrm{~g})$ and the $10 \%$ higher nominal dose $(3.3 \mathrm{mg})$, after two weeks in wet soil the mean 1080 content was $0.69 \pm 0.11 \mathrm{mg}(n=2)$.

With no rain, the degradation of 1080 in Foxoff ${ }^{\circledR}$ is highly variable but considerably slower than in wingettes under similar conditions. After three weeks, no wingettes from any treatment $(n=16)$ contained detectable levels $(>0.05 \mathrm{mg})$ of 1080. By contrast, many Foxoff ${ }^{\circledR}$ baits still contained sufficient 1080 to be hazardous to a fox or dog after 11 weeks (Saunders et al. 2000). Similarly, the results can be used to estimate potential impacts of baiting campaigns on non-target species (Table 2). On agricultural lands in eastern New South Wales, the main non-target species at risk from 1080 poisoning are domestic and working dogs. Dogs are highly susceptible to 1080, with an $\mathrm{LD}_{50}$ of $0.066 \mathrm{mg} \mathrm{kg}^{-1}$ (Tourtellotte and Coon 1951). Withholding periods should be calculated to ensure that dogs are excluded from baited areas until the baits pose a minimal risk to any dogs that may consume it. Given that only one in six dogs died at $0.05 \mathrm{mg} \mathrm{kg}^{-1}$ (Tourtellotte and Coon 1951), the lower risk posed at this dose level (i.e. an estimated $17 \%$ ) would be more acceptable than at $0.66 \mathrm{mg} \mathrm{kg}^{-1}$ (i.e. an estimated $50 \%$ ). If an average-sized sheep dog weighs $15 \mathrm{~kg}$ and a cattle dog weighs $20 \mathrm{~kg}$ (Fleming and Parker 1991), they would need to ingest doses not less than 0.75 and $1.00 \mathrm{mg}$ respectively to be at serious risk of 1080 poisoning.

Landholders in New South Wales are legally required to remove and dispose of all untaken baits at the completion of a baiting program (Environment Protection Authority 2002). However, foxes often cache baits, resulting in baits that cannot be retrieved and which constitute threats to working dogs. The results from this study and Saunders et al. (2000) suggest that areas baited with Foxoff ${ }^{\circledR}$ require longer withholding periods, especially during dry periods, than areas baited with wingettes. Dry periods would be particularly dangerous since some Foxoff ${ }^{\circledR}$ baits retained high 1080 concentrations for extended periods. In wet soil conditions, at least four weeks are needed after the last baits are laid before working dogs should be allowed on properties baited with Foxoff ${ }^{\circledR}$, twice as long as required when wingettes are used. Consequently, it may be better to use wingettes in sensitive areas where long-term hazards from toxic baits are highly undesirable, or when shorter withholding periods for working dogs are required to ensure 'safety', regardless of season.

Increased longevity of bait can also be advantageous. Obviously, bait must remain toxic for long enough to ensure that resident foxes will find and consume a lethal dose. If bait degrades too rapidly for foxes to have this opportunity, it may reduce the efficacy of baiting programs. Reduced longevity would require bait to be replaced more often in continuous baiting programs, reducing cost-effectiveness. Saunders et al. (2000) suggested that consumption of a sublethal dose of 1080 from degraded bait may lead to bait aversion, thus reducing the likelihood of bait being consumed on subsequent encounters. Research is therefore needed to determine whether the uptake of wingettes by foxes occurs before deterioration to sublethal levels. If baits are not retrieved (e.g. if deployed aerially), bait longevity may also add a 'time buffer' effect by remaining active to reduce the effect of reinvasion by immigrant foxes (Twigg et al. 2000).

There is some experimental evidence that foxes can form learned aversions to illness-inducing baits (Gentle et al. 2004; Baker et al. 2007). In addition to generating bait aversion, presenting bait of low toxicity may provide a mechanism to generate resistance to toxins. Ingestion of low-toxicity bait has been suggested as a potential cause of rabbits evolving resistance to 1080 in some areas of Western Australia (Twigg et al. 2002). If 1080 resistance were to develop in foxes and other predators, the viability of poisoning operations would be severely compromised. Resistance to 1080 may decrease the efficacy of poisoning operations, or result in greater amounts of 1080 being required in bait to effectively target such animals. Additionally, given that a major benefit of using 1080 for introduced predators such as foxes and wild dogs is their relatively high susceptibility compared with native species (McIlroy 1981, 1986), any resistance may reduce this benefit by requiring that additional 1080 be added to bait. Baiting strategies should avoid contributing to the development of 1080 resistance by ensuring that bait consumed to foxes contains sufficient 1080 for a lethal dose.

This study has also highlighted some important considerations for baiting strategies. The 1080 content of baits prepared experimentally, when great care and attention is given, should be more consistent than that for non-commercially prepared baits used in routine fox control. Given the variability encountered under these experimental conditions, this is a concern and suggests that the variation in 1080 content of fresh baits used in everyday campaigns is likely to be greater. Furthermore, variation in the physical state of meat baits would be expected due to differences in the preparation techniques and equipment and the state of the bait when presented in the field. 
Bait is prepared whilst fresh but, depending on the period and method of storage (i.e. refrigerated or not) between preparation and presentation, bait may be laid in a condition ranging from fresh to spoiled. This inconsistency is a concern given that effective fox-control strategies rely on presenting bait with a known, accurate dosage of 1080 - all determined from freshly prepared bait. This is based on expectations of efficacy and reduced non-target risk with dose rates prescribed by pesticide legislation. Further consideration of these issues is required to ensure the responsible and effective use of 1080 for fox control.

\section{Acknowledgements}

Queensland Department of Primary Industries and Fisheries were contracted to undertake the bait assays. We thank Laurie Twigg and Bob Parker for technical advice, and Greg Jones, Brian Lukins and Jayne Jenkins for technical assistance. Thanks to John Mcllroy and two anonymous referees for comments. Funding for this research was provided by the National Feral Animal Control Program (NHT) and the Invasive Animals CRC.

\section{References}

Adams, M. R., and Moss, M. O. (1995). 'Food Microbiology.' (The Royal Society of Chemistry: Cambridge.)

Baker, S. E., Johnson, P. J., Slater, D., Watkins, R. W., and Macdonald, D. W. (2007). Learned food aversion with and without an odour cue for protecting untreated baits from wild mammal foraging. Applied Animal Behaviour Science 102, 410-428. doi: 10.1016/j.applanim.2006.05.039

Calver, M. C., and King, D. R. (1986). Controlling vertebrate pests with fluoroacetate: lessons in wildlife management, bioethics and co-evolution. Journal of Biological Education 20, 257-267.

Dickman, C. R. (1996). Impact of exotic generalist predators on the native fauna of Australia. Wildlife Biology 2, 185-195.

Eastman, A., and Calver, M. C. (1988). Consumption of dingo baits by non-target fauna from the pastoral areas of Western Australia. Australian Rangelands Journal 10, 106-108. doi: 10.1071/RJ9880106

Environment Protection Authority (2002). Pesticide Control (1080 fox bait) Order 2002. Government Gazette No. 225, 9993-10012.

Fleming, P. J. S., and Parker, R. W. (1991). Temporal decline of 1080 within meat baits used for control of wild dogs in New South Wales. Wildlife Research 18, 729-740. doi: 10.1071/WR9910729

Frazier, W. C., and Westhoff, D. C. (1978). 'Food Microbiology.' 3rd edn. (McGraw-Hill: New York.)

Frost, R. L., Parker, R. W., and Hanna, J. V. (1989). Detection of the pesticide compound 1080 (sodium monofluroacetate) using fluorine-19 nuclear magnetic resonance spectroscopy. The Analyst 114, 1245-1248. doi: 10.1039/an9891401245

Gentle, M., Massei, G., and Saunders, G. (2004). Levamisole can reduce bait monopolization in wild red foxes, Vulpes vulpes. Mammal Review 34, 325-330. doi: 10.1111/j.1365-2907.2004.00049.x

Griffiths, M. E. (1959). The effect of weathering on the toxicity of baits treated with sodium fluoroacetate. CSIRO Wildlife Research 4, 93-95.

Hannan-Jones, M. (2002). AF20020109: Determination of fluoroacetate in chicken wingettes and Foxoff baits to assess their degradation in the environment. Alan Fletcher Research Station Pest Management Chemistry Report. Department of Natural Resources and Mines, Sherwood.

King, D. R., Kirkpatrick, W. E., Wong, D. H., and Kinnear, J. E. (1994). Degradation of 1080 in Australian soils. In 'Proceedings of the Science Workshop on 1080. Miscellaneous Series 28'. (Eds A. A. Seawright and C. T. Eason.) pp. 45-49. (The Royal Society of New Zealand: Wellington.)

Kinnear, J. E., Sumner, N. R., Onus, M. L. (2002). The red fox in Australia - an exotic predator turned biocontrol agent. Biological Conservation 108, 335-359. doi: 10.1016/S0006-3207(02)00116-7
Kirkpatrick, W. E. (1999). Assessment of sodium monofluroacetate (1080) in baits and its biodegradation by microorganisms. M.Sc. Thesis, Curtin University of Technology, Perth.

Korn, T. J., and Livanos, G. (1986). The effect of dosing technique on the 1080 content of meat baits. Australian Wildife Research 13, 455-460. doi: 10.1071/WR9860455

Kramer, H., and Merrell, P. (1987). Use of sodium fluoroacetate (compound 1080 ) in the control of dingoes 1 . Meat bait preparation techniques. Australian Wildlife Research 14, 65-68. doi: 10.1071/WR9870065

Kramer, H. L. (1984). Liquid chromatographic determination of sodium fluoroacetate (compound 1080) in meat baits and formulations. Journal - Association of Official Analytical Chemists 67, 1058-1061.

McLeod, R. (2004). 'Counting the Cost: Impact of Invasive Animals in Australia 2004.' (Pest Animal Control Cooperative Research Centre: Canberra.)

McIlroy, J., and Gifford, E. (1988). The effect of rainfall and blowfly larvae on the toxicity of 1080 treated meat baits used in poisoning campaigns against wild dogs. Australian Wildlife Research 15, 473-483. doi: 10.1071/WR9880473

McIlroy, J. C. (1981). The sensitivity of Australian animals to 1080 poison. II. Marsupial and eutherian carnivores. Australian Wildlife Research 8, 385-399. doi: 10.1071/WR9810385

McIlroy, J. C. (1986). The sensitivity of Australian animals to 1080 poison. IX. Comparisons between the major groups of animals, and the potential danger non-target species face from 1080-poisoning campaigns. Australian Wildlife Research 13, 39-48. doi: 10.1071/WR9860039

McIlroy, J. C., and King, D. R. (1990). Appropriate amounts of 1080 poison in baits to control foxes, Vulpes vulpes. Australian Wildlife Research 17, 11-13. doi: 10.1071/WR9900011

McIlroy, J. C., Cooper, R. J., Gifford, E. J., Green, B. F., and Newgrain, K. W. (1986). The effect on wild dogs, Canis f. familiaris, of 1080-poisoning campaigns in Kosciusko National Park, NSW. Australian Wildlife Research 13, 535-544. doi: 10.1071/WR9860535

Oogjes, G. (1996). The ANZFAS view of vertebrate pest control using chloropicrin fumigation and 1080 poisoning. In 'Humaneness and Vertebrate Pest Control'. (Eds P. M. Fisher and C. A. Marks.) pp. 9-12. (Ropet Printing: Melbourne.)

Ozawa, H., and Tsukioka, T. (1989). Determination of sodium monofluroacetate in soil and biological samples as the dichloroanilide derivative. Journal of Chromatography 473, 251-259. doi: 10.1016/ S0021-9673(00)91306-2

Parfitt, R.L., Eason, C. T., Morgan, A. J., Wright, G. R., and Burke, C. M. (1994). The fate of sodium monofluoroacetate (1080) in soil and water. In 'Proceedings of the Science Workshop on 1080. Miscellaneous Series 28'. (Eds A. A. Seawright and C. T. Eason.) pp. 59-66. (The Royal Society of New Zealand: Wellington.)

Robards, G. E., and Michalk, D. L. (1975). An evaluation of dryland pastures for sheep grazing at Trangie. Final report to Australian Wool Corporation and Department of Agriculture, NSW. Department of Agriculture, NSW, Sydney.

Saunders, G., and McLeod, L. (In press). Fox management strategies a review of recent developments. Bureau of Resource Sciences, Australian Government Publishing Service, Canberra.

Saunders, G., Coman, B., Kinnear, J., and Braysher, M. (1995). 'Managing Vertebrate Pests: Foxes.' (Australian Government Publishing Service: Canberra.)

Saunders, G., McLeod, S., and Kay, B. (2000). Degradation of sodium monofluoroacetate (1080) in buried baits. Wildlife Research 27, 129-135. doi: 10.1071/WR99031

Snedecor, G. W., and Cochran, W. G. (1989). 'Statistical Methods.' 8th edn. (Iowa State University Press: Ames, IA.)

Staples, L., McPhee, S., Bloomfield, T., and Wright, G. (1995). Foxoff fox baits: stability, lethal efficacy and degradation in soil. In 'Proceedings of the 10th Vertebrate Pest Control Conference, Hobart'. pp. 444-445. 
Tourtellotte, W. W., and Coon, J. M. (1951). Treatment of fluoroacetate poisoning in mice and dogs. Journal of Pharmacology and Experimental Therapeutics 101, 82-91.

Twigg, L. E., Eldridge, S. R., Edwards, G. P., Shakeshaft, B. J., de Preu, N. D., and Adams, N. (2000). The longevity and efficacy of 1080 meat baits used for dingo control in central Australia. Wildlife Research 27, 473-481. doi: 10.1071/WR99044

Twigg, L. E., Kok, N. E., Kirkpatrick, W. E., and Burrow, G. (2001). The longevity of 1080 egg-baits in a regularly baited nature reserve in south-western Australia. Wildlife Research 28, 607-618. doi: 10.1071/WR00095

Twigg, L. E., Martin, G. R., and Lowe, T. J. (2002). Evidence of pesticide resistance in medium-sized mammalian pests: a case study with 1080 poison and Australian rabbits. Journal of Applied Ecology 39, 549-560. doi: 10.1046/j.1365-2664.2002.00738.x

Venables, W. N., and Ripley, B. D. (2002). 'Modern Applied Statistics with S.' 4th edn. (Springer: New York.)

Weaver, S. (2003). Policy implications of 1080 toxicology in New Zealand. Journal of Rural and Remote Environmental Health 2, 46-59.

West, P., and Saunders, G. (2003). Pest Animal Survey 2002 - an analysis of pest animal distribution and abundance across NSW and the ACT. NSW Agriculture, Orange.
Wheeler, S. H., and Oliver, A. J. (1978). The effect of rainfall and moisture on the 1080 and pindone content of vacuum-impregnated oats used for control of rabbits, Oryctolagus cuniculus.. Australian Wildlife Research 5, 143-149. doi: 10.1071/WR9780143

Williams, J. M. (1994). Food and fibre markets and societal trends: implications for pest management. In 'Proceedings of the Science Workshop on 1080. Miscellaneous Series 28'. (Eds A. A. Seawright and C. T. Eason.) pp. 20-32. (The Royal Society of New Zealand: Wellington.)

Winstanley, R. K., Buttemer, W. A., and Saunders, G. (1999). Fat deposition and seasonal variation in body composition of red foxes (Vulpes vulpes) in Australia. Canadian Journal of Zoology 77, 406-412. doi: 10.1139/cjz77-3-406

Wong, D., Kirkpatrick, W., Kinnear, J., and King D. (1991). Defluorination of sodium monofluoroacetate (1080) by microorganisms found in bait materials. Wildlife Research 18, 539-545. doi: 10.1071/WR9910539

Manuscript received 28 November 2006, accepted 25 May 2007 